\title{
Investments in Braskem Green Polymers: Extraordinary Profits Instead of Decarbonization of the Environment
}

\author{
Eliana Leal Hellvig, Thais Helena Sydenstricker Flores-Sahagun \\ Mechanical Engineering Department, Federal University of Paraná, Curitiba, Paraná, Brazil \\ Email address: \\ elianalealf@yahoo.com.br (E. L. Hellvig)
}

\section{To cite this article:}

Eliana Leal Hellvig, Thais Helena Sydenstricker Flores-Sahagun. Investments in Braskem Green Polymers: Extraordinary Profits Instead of Decarbonization of the Environment. International Journal of Sustainable Development Research. Vol. 7, No. 1, 2021, pp. 17-27.

doi: $10.11648 /$ j.ijsdr.20210701.13

Received: December 1, 2020; Accepted: December 9, 2020; Published: April 26, 2021

\begin{abstract}
This paper presents an evaluation with the use of patentometry of how the technologies for the production and use of green polyethylenes (HDPE - high density polyethylene and LLDPE - linear low density polyethylene) and green polypropylene evolved from 1999 to 2017. The results of this research enabled to identify companies that invested in technologies for the production of green polyethylenes (PEs) and polypropylene and the reasons for the fall in investment in $\mathrm{R} \& \mathrm{D}$ in the period studied. The fundamental reason for selecting Braskem for the case study is that although the company is not the largest patent holder for the technology considered, it is the only company that commercially produces green PEs in the world. Although the performance of green and fossil nominally same PEs are equivalent, commercial clients may use blends of up to $51 \%$ of green polyethylene and $49 \%$ of fossil polyethylene and still have the right to use the I'm green ${ }^{\mathrm{TM}}$ label. Moreover, the marketing which involves the sale of green PEs to companies that use polymers with the "I'm Green" ${ }^{\mathrm{TM}}$ " label from Braskem appeals to environmental conscious consumers and places these companies in a noticeable position. The LOX (Sarbanes Oxley Law) is an agreement between world stock exchanges which provides for good governance, that is, the transparency of financial acts. In Brazil, it is observed in the São Paulo Stock Exchange (B3) the lack of rigorous inspection in the inventories of emission of green stocks by companies. There is no transparency in how carbon credits were gained and in the AIS - Annual Income Statement of green stocks BRKM5. As a result, this led to the investigation that culminated in the analysis of green PEs as commodities in the financial market as well as relations concerning the investors in the green stock market (BRKM5). The Annual Income Statement - AISs from 2010, when Braskem started production of green PEs, until 2018, show there was growth of revenues. Despite of the production of PEs have continued stable and the number of green PEs patents have decreased since 2014, the profits with the BRKM5 stocks increased and in 2018 extraordinary profits were obtained. In 2012 the average share price of BRKM5 was R $\$ 13.27$ and in 2018, the average price reached R\$ 48.93 per share, representing an increase of $268 \%$ and extraordinary profits.
\end{abstract}

Keywords: Carbon Credits, Green Polyethylene, Braskem, I'm Green, BRKM5, Patents

\section{Introduction}

Green plastics have received special attention from industry and governments around the world as they a reproduced from raw materials of vegetable origin and can contribute to the reduction of Green House Gas (GHG) emissions and the environmental pollution generated by plastic, which cause severe damage to ecosystems and the quality of life of the world's population. In this context, this paper presents a case study about Braskem, the only company that produces green polyethylenes obtained from sugarcane in the world [1], aiming to discuss issues related to the gains that companies have when investing in green polymers and their potential impact in decarbonizing the environment.

It is important to address transparency and compliance in the world trade business because confidence attracts new investors, stakeholders and customers [2, 3]. Innovative green technology is an important tool to obtain international competitive advantages in the global markets and some authors consider that the quality of products is the best guarantee in the long-term competitiveness of firms and 
countries.[4] However, transparency (in carbon credits and AIS-Annual Income Statement of green stocks BRKM5) should be of utmost importance to consolidate the company in the global market because it shows consumers, commercial clients and stakeholders that investments in green technologies contribute effectively to generate environmental benefits besides profits. Braskem, a huge Brazilian company, places Brazil in a noticeable position regarding the production of green polyethylenes and other products. It is essential that Brazil is seen as a country where good corporate governance practices are adopted so that investors can bring new opportunities for the country. In fact, Braskem also trades in other stock exchange markets throughout the world and should be completely transparent. Whenever lack of transparency occurs, it should be addressed and rectified. However, we were informed that only share holders have access to this information according to the regulations currently in force in the financial market, as stablished by São Paulo stock exchange (B3) and the Securities and Exchange Commission of Brazil (CVM).

However, B3 is agreed to the international financial market rules in 2007, such as the Sarbanes Oxley Act (SOX), which determines transparency of all business activities. Therefore, B3 must share the reports with the public. Thus, noncompliance with the rule was observed.

In order to better understand these issues, Braskem's innovation and technological development related to green polyethylene's (PEs) and polypropylene (PP), the role of carbon credits as financial instruments for the decarbonization of the environment will initially be addressed. In the Results and Discussion section, the evolution of patents for green PEs and green PP filed at the United States Patent and Trademark Office-USPTO from 1999 to 2017 will be evaluated from the point of view of market concentration, among other issues such as the companies that have invested the most in these technologies and the types of products that can be manufactured. The study will also discuss the advantages of the use of Braskem green polymers by corporate customers and their gains in terms of marketing and image promotion; the gains of BRKM 5 from 2007 to 2018 in the São Paulo stock exchange (B3); and the gains from carbon credits.

Green ethene, monomer used in the production of green polymers, is obtained from the dehydration of ethanol $[1 ; 5]$. The United States of America (USA) and Brazil are the main producers of ethanol in the world, and ethanol produced in the USA is obtained from corn and, in Brazil, from sugarcane [6]. Although ethanol produced from corn and sugarcane - as well as from other raw materials of vegetable origin, such as corn, cassava and beet - are equal products, considering the total production cycle, only ethanol from sugarcane removes $\mathrm{CO}_{2}$ from the environment [6-8]. Thus, the production of green ethene from the dehydration of sugarcane ethanol is valuable because, besides opening a wide range of possibilities for the production of green and more environmentally friendly polymers, it generates carbon credits. It is important to note, however, that although green ethene comes from a renewable source, green polyethylenes and green polypropylene are not biodegradable polymers and may be as pollutant as the fossil same polymers.

There is a controversy in the literature regarding the values of decarbonization of the environment through the production of sugarcane ethanol. According to [9], each ton of green ethane removes 3.5 ton of $\mathrm{CO}_{2}$ from the environment, while for [10] the value is 2.5 tons. The lifecycle greenhouse gas emissions and energy balances of sugarcane ethanol production in Mexico and in Brazil was discussed elsewhere [8]. However, in the Braskem site there is a video where the information is that each ton of green ethene removes 4.75 ton of $\mathrm{CO}_{2}$ from the environment and this value will be used in this case study for the calculation of carbon credits owed by the green ethene production [11]. Case studies of specific countries or companies are interesting to evaluate clean technologies worldwide [11-14].

This study includes a survey of the technologies protected by patents of invention used in products and processes for obtaining green PEs (HDPE-high density polyethylene and PELBD-linear low density polyethylene) and green PP filed in the USPTO patent data base in a period of 18 years. In this work, through the related patentometry [15] it was evaluated how the technologies for the production and use of polyethylenes (PEs) and green polypropylenes evolved from 1999 to 2017. The USPTO was chosen because it has a wider scope, when compared to the European patent office. Another relevant factor is that, by providing greater access to information, it makes it possible to answer a greater number of questions related to the development of research in the sector, as well as discussing issues related to the gains that companies have when investing in green polymers.

It was concluded that the USA has a high concentration of companies holding patents on green PEs and PP, although they do not produce these polymers. This could mean that the major goal of research and development (R\&D) investments is to own technology and obtain gains through royalties from technology transfer. Braskem's marketing strategy with the

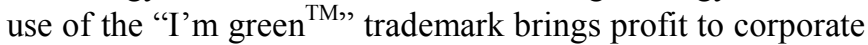
customers who use this label to promote a positive image of their companies. Braskem has had capital gains from carbon credits since 2010, when the production of green ethene from sugarcane began. With the financial speculation of BRKM5, Braskem's green shares, on B3, the average share price increased 268\% between 2012 and 2018. When analyzing Braskem's Annual Income Statements (AISs) from 2007 to 2010, the year in which the production of green PE was commercially launched, it was observed that the company had its earnings increased. Braskem might have much larger capital gains with carbon credits than its AIS; there is no transparency when it comes to the trading of BRKM5 assets or carbon credits. The Sarbanes-Oxley-Sox Law [16] signed in the USA in 2002 and applied in Brazil since 2007, at the time of their structuring of the São Paulo stock exchange [17], determines that all companies that participate in the financial market adopt good corporate governance practices (compliance). The Central Bank of Brazil (BACEN) has the 
role to supervise the National Financial System in Brazil but although transparency is said to be mandatory in order to corporate customers trade in the B3, only investors may have access to this information [18].

The main objective of the paper was to show how a Brazilian company, Braskem, manages to make extraordinary profits using the production of green polymers, environmental appeal and a marketing strategy that uses the "Im Green ${ }^{\mathrm{TM}_{1}}$ label on non-bio degradable plastics (green HDPE and LLDPE) produced from ethene derived from the dehydration of sugarcane ethanol. Innovative green technology may attract new stakeholders, commercial clients and consumers. However, transparency in carbon credits report and AIS of greens stocks BRKM5 are essential in order to guarantee a long-term international competitiveness of Braskem.

\section{Innovation and Technological Development of Braskem Green PEs}

Green polyethylenes (PEs) are only produced in Brazil at the Triunfo petrochemical complex, in the state of Rio Grande do Sul, which has a production capacity of 200,000 tons per year. The ethanol used in the production of green PEs is largely provided through contracts with major domestic producers, whose relationship with Braskem is governed by the Code of Conduct for Ethanol Suppliers (CCFE), so that good practices are implemented [19].

The "I'm green" TM" PEs replace conventional PEs without the need for investments in new plastic processing machines because they are essentially the same polymers as the equivalent fossil ones [20-23]. Green or fossil polyethylenes are not biodegradable but green PEs are biopolymers because the main raw material is green ethene and both are recyclable. Polyethylenes, green and fossil, are recyclable and more resistant, especially to moisture, than the biodegradable polymers. Packaging is the main application of polyethylenes. Although many authors have developed biodegradable materials such a hemicellulose/chitosan films [24], soy protein films [25-26], Cassia gum films [27] for packaging, polyethylenes are the most common polymers used. Green composites [28-29], nanocellulose composites [30] and PLA/cellulose nanocrystal composites [31] are green materials [5] such as plasticized poly (3-hydroxybutyrate), cellulose/poly(butylenesuccinate) composites [32, 33] and starch based polymers [30] but do not replace polyethylenes due to its durability, resistance to water and lower cost.

In 2010, Vinçotte, the Belgian inspection and certification organization, certified the renewable content of Braskem's green polyethylenes. Renewable content of green PEs and green PP is one of the most important attributes and it expresses the percentage of renewable carbon relative to the total mass of the material or product [34]. Braskem's HDPE presents a minimum renewable content of $96 \%$ while LLDPE, a copolymer of green ethene and fossil hexene or butane, shows a minimum renewable content of $89 \%$. Although the renewable content of green LLDPE could be increased if butene and hexene of vegetable origin were used, the cost would probably be not economically viable [35].

Braskem's green PEs are the only ones produced on an industrial scale in the world. Conventional PEs (HDPE and LLDPE) can be replaced by equivalent green polymers, since they are nominally equal products. However, subtle differences that do not alter their performance may exist, since ethene from ethanol dehydration is purer than that from oil fractionation [14; 36-39]. In our study, we also analyzed two pairs of fossil and green polyethylenes. Braskem data sheet of nominally same HDPE fossil and green (HC7260 and SHC7260) and of same LLDPE fossil and green (LL318 and SLL318) show that all properties listed (mechanical, density and some thermal properties) are the same. We have compared the two pair of polymers regarding composition and chemical structure and we found subtle differences between the pairs which do not affect their macroscopic performance [39]. Green HDPE may be considered a natural composite containing approximately $10 \mathrm{wt} \%$ of inorganic filler, since thermoanalysis (TGA) showed the presence of a residue of inorganic compounds, while fossil HDPE burnt completely in air. Nuclear magnetic resonance (NMR) of the two LLDPE samples showed that the ethene/butane incorporation in the polymer was different and, as also suggested by $\mathrm{x}$-ray analysis, the green copolymer was more crystalline [39]. Therefore, there would be no technical reason to mix the cheaper fossil polymer with the green one unless the purpose is to obtain a cheaper material. However, Braskem allows its clients to mix fossil PE with green PE alleging technical reasons and if the mixture has at least $51 \%$

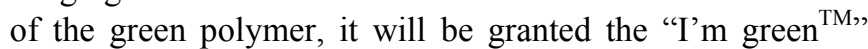
seal, which results in gains in terms of marketing and the promotion of the company's image to consumers. Thus, even with the mixing of green and fossil content-which results in a $49 \%$ greater volume of material - due to the increasing in the percentage of the fossil polymer at a lower price since the green polymers are more expensive, the product can receive

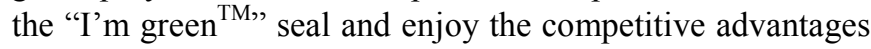
associated to it.

Although Braskem requires the disclosure of any product that contains green HDPE or LLDPE in its composition in a transparent manner, mentioning the percentage of polymer

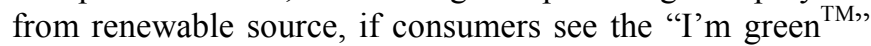
seal in a packaging, they will probably assume the material is fully green [11].

The development of new technologies in the production of polymers obtained from renewable sources is a key to sustainability, even though only about $4 \%$ of the oil produced in the world feeds the polymer industry [40]. Thus, the development and use of alternative energy sources (clean technologies) such as wind, solar, tidal, hydro and nuclear, rather than the use of oil, would lead to a drastic reduction of GHG emissions [41, 42]. However, environmental pollution caused by plastics, low density materials that are often discarded in the form of packaging in inappropriate places, contaminates oceans, rivers and cities in a very destructive manner, severely affecting the flora of the planet [10]. In 
2015, 407 million tons of plastic were produced worldwide and $35.9 \%$ of this total was used in packaging. Of these 407 million tons, 302 million tons formed plastic waste, with only $20 \%$ of the total being recycled, $25 \%$ incinerated, and $55 \%$ discarded [43]. Therefore, the development of more resistant biodegradable polymers is crucial and so is the management of the recycling process of plastics, so that they can be reused, increasing their life-span and promoting the final disposal in selected locations [44]. The development of clean technologies such as green polymers by Braskem demonstrates concern for the environment, its decarbonization and conservation, although green polyethylenes are not biodegradable. Also, it shows interest in the profit that can be obtained in the commercialization and use of these technologies.

\section{Carbon Credits as an Economic Instrument to Decarbonize the Environment}

The Kyoto Protocol, signed on December 11, 1997 in Japan is the regulatory framework for the clean development mechanism. This international instrument was ratified on March15, 1998 and officially entered in to force on February 16, 2005. The Protocol represented a milestone in international efforts to address climate change, establishing a legal commitment to reduce GHG emissions. This regulatory framework is notable for allowing the pricing of GHGs and the transaction of reduction certificates between the signatory parties, which represents an incentive for investment in alternative, lower emissions technologies [45].

The Kyoto Protocol, the international agreement which established that developed countries should reduce their GHG emissions, has encouraged industries to see alternatives to reduce emissions, to develop new technologies that could generate carbon credits, or to buy carbon credits from less developed countries. The premise underlying the agreement is that green chemistry and the use of clean technologies contribute to sustainable development and minimize the environmental impact caused by population growth and its material and energy needs.

Carbon assets are priced through the stock exchange. Pricing carbon means determining the price of the GHG emission certificates for air polluters such as industries, agroindustries, oil refineries and others with carbon-intensive activities. The larger the industries footprints are, more expensive their products would become because there are costs that are shared among all citizens through over burdened health services, water and food shortages, and increased damage from floods or hurricanes - the so - called negative externalities from GHG emissions. On the other hand, cleaner products would be cheaper and this is the so called process of decarbonization of the economy. Braskem produces each year 16 million tons of fossil polyethylenes and only 200.000 ton of green polyethylenes [11].

The São Paulo Stock Exchange (B3) is responsible for developing and deploying systems of trading and post- trading services (clearing and settlement) of shares; shares, financial and commodities derivatives; fixed-income securities; federal public securities; spot currencies and agricultural commodities, among others. The main role of the stock exchange is to foster the national stock market in a transparent manner, following the international rules for good financial market governance practices (compliance).

Carbon credits can be defined as certificates that companies or countries buy to obtain permission to emit GHGs, where one carbon credit corresponds to one ton of carbon. GHGs are converted into units of carbon dioxide equivalent $\left(\mathrm{CO}_{2} \mathrm{e}\right)$ that can be reduced, avoided or sequestered to compensate for emissions occurring in other places and activities. $\mathrm{CO}_{2} \mathrm{e}$ is the result of multiplying tons of the emitted GHGs by its global warming potential. The global warming potential of carbon dioxide was set as 1 ; whereas methane has global warming potential of 21 , i.e., one ton of sequestered methane corresponds to 21 carbons [17].

The Rio de Janeiro Stock Exchange (BVRIO) offered in 2015 a carbon market simulation platform, for buying and selling carbon credits. The rules and parameters of the simulation were built in 2013, along with participating companies, based on the emissions trading systems in operation, such as the California Stock Exchange and the European Union. BVRIO works with companies that have adhered to the clean development mechanisms agreed in the Kyoto Protocol, thus it is considered a green market. The companies participating in the initiative must reconcile their emissions from the current cycle with emissions certificates that entitle them to emit one ton of $\mathrm{CO}_{2} \mathrm{e}$.

\section{Materials and Methods}

The development of patents allows companies to own new technologies. The patent holder has the right to prevent third parties from producing, using, selling or importing a product subject to his or her patent and process, or processes and products obtained directly from such patent, without his or her consent. Patents reveal the technical content of the protected matter and the search in patent offices is a very useful tool when solving a specific technical problem, because it avoids duplication of R\&D activities. A patentometric analysis was used as a tool and the keywords used in the patents search were GPE (green polyethylene), GPP (green polypropylene, PEverde, PP (polypropylene), LDPE (low density polyethylene), LLDPE (linear low density polyethylene) and HDPE (high density polyethylene) [15; 46]. São Paulo Stock Exchange (B3) site and links were used to obtain financial data from Braskem (Annual Income Statement- AIS, information about BRKM5, BRKM3 and BRKM6).

This study used the USPTO patent data base for data collection, which occurred during a period of 12 months, from January 2017 to January 2018. After collection, the data were organized according to the following criteria: Country of origin of the patent x Quantity, Application x Quantity, and 
Type of green polymer x Quantity.

Finally, the data were organized for evaluation and quantitative analysis.

\section{Results and Discussion}

\subsection{Evolution of Green Polymer Patents in the USPTO from 1999 to 2017}

Patentometry allows technological activities to be known, technical changes over time to be analyzed and resources invested in R\&D activities to be evaluated [46]. The search in the USPTO data base was made using keywords cited in the methodology and resulted in 8.226 related patents of which 1.216 came with their number, and title. However, it was necessary to read all the specifications found in order to separate the patents relating to fossil raw material from non-fossil, i.e., those specifications that actually referred to green plastics. Only 123 documents out of 1216 were selected because they were patents related to green ethene. The country with the highest number of patents is the USA, with 93 patents, followed by Brazil, with 12 patents, and Japan, with 9 patents. Also, regarding type of green plastic, 58 patents are for green PEs, 29 for green PP and 36 for both.

Even though the USA appears as the country with the highest number of green patents, it does not produce green PEs or PP, nor does it produce the raw material, ethanol from sugarcane. The dehydration of corn ethanol does not generate carbon credits, despite being the same product as the ethene obtained from the dehydration of ethanol from sugarcane, considering the entire production cycle. It is interesting to note that Japan, England and Germany have invested in technologies for the production of green PEs, and the raw material used in the production of ethanol is often obtained from beet, sorghum and cellulose. In these cases, the interest in the detention of these technologies surpasses the possibility of producing polymers that generate carbon credits, since these raw materials do not remove more $\mathrm{CO}_{2}$ than they produce.

Braskem provided green ethene for the development of 30 of the 93 USA patents. Today, Braskem is the largest shareholder of Dow, which appears in 18 USA patents, supplying the green ethene produced by Braskem. Metabolix and the University of Southampton appear using cellulose and beet, respectively, as raw material for the production of ethanol. Of the 123 patents granted, 54 are for processes and 69 are for products. From the 123 patents selected at the USPTO, it is possible to state that 19 were for films, 12 for packaging, and 12 for bottles, that is, the pharmaceutical, food and cosmetic industries are the ones that invest the most in this market. The automotive and medical products sectors appear with 3 documents each.

The highest number of patents takes place between 2010 and 2013, and this period coincides with initiatives generated by the Kyoto Protocol for the reduction of GHG emissions from 2008 to 2012. Another piece of information that reinforces this data is that Braskem, the world leader in the production of green $\mathrm{PE}$, began its production of green $\mathrm{PE}$ in Rio Grande do Sul in 2010.

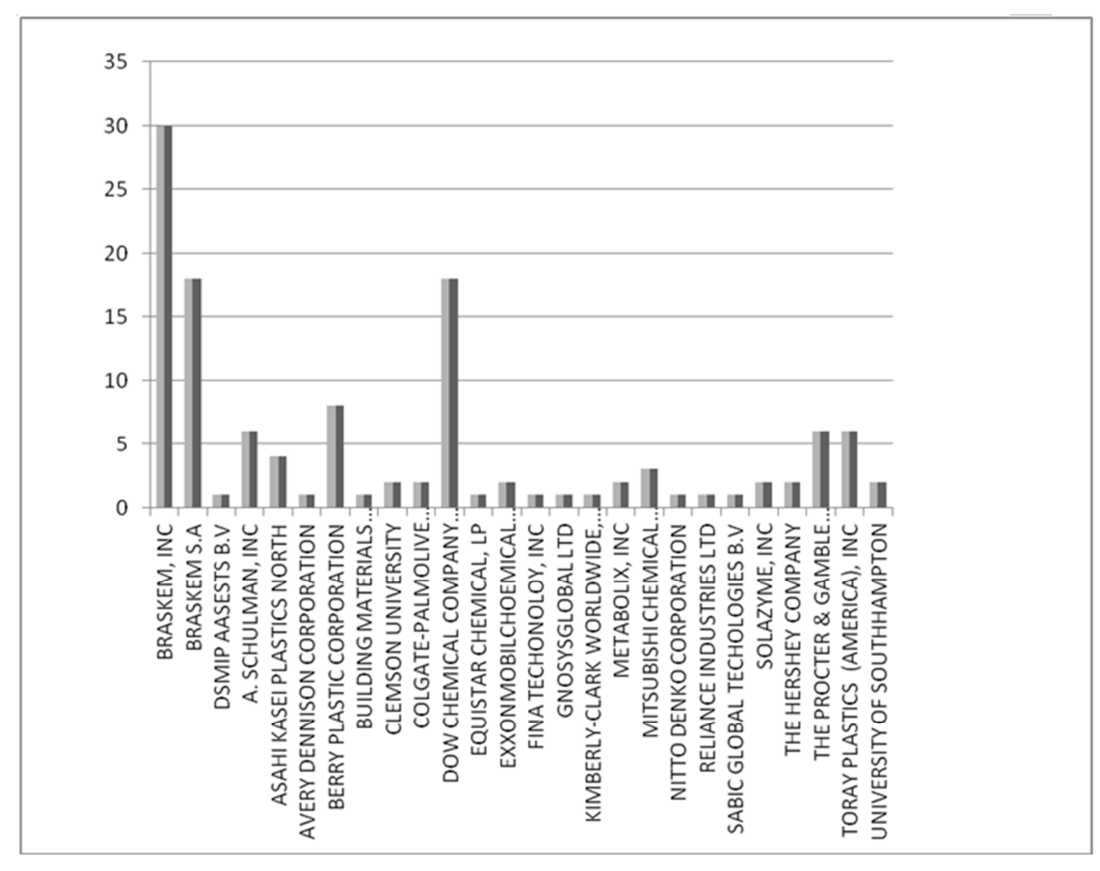

Source: Prepared by the author (2018)

Figure 1. Companies that appear in the patent specifications surveyed.

\subsection{Statistics for Market Concentration}

Table 1 describes the statistical calculations of the data selected to subsequently identify the Herfindahl-Hirschman Index (HHI), which indicates the number and size of companies/firms/countries in a given sector or market. 
Table 1. Variance, standard deviation and coefficient of variation: green PE and PP.

\begin{tabular}{llll}
\hline \multicolumn{2}{l}{ STATISTICAL TABLE RESULTS } & & \\
\hline & & AVERANGE & RELATIVE FR \\
\hline TYPE OF POLYMER & FREQUENCY (FR) & & \\
Green PE & 58 & $58 / 123=0,4715$ & $0,4715 X 100=47,15 \%$ \\
Green PP & 29 & $29 / 123=0,2357$ & 0,2357 X100 $=23,57 \%$ \\
Green PP + PE & 36 & $36 / 123=0,2926$ & 0,2926 X $100=29,26 \%$ \\
RESULTS & 123 & 123 & \\
& & $123 / 3=41$ & \\
APLICATION & FREQUENCY (FR) & AVERANGE & 0,5609 X $100=56,09 \%$ \\
PROCESS & 69 & $69 / 123=0,5609$ & $0,4390 X 100=43,90 \%$ \\
PRODUCT & 54 & $54 / 123=0,4390$ & \\
\hline
\end{tabular}

Table 1. Continued.

\begin{tabular}{llll}
\hline & \multicolumn{2}{l}{ STATISTICAL TABLE RESULTS } & \\
\cline { 2 - 4 } & $\mathbf{S}^{2}=$ VARIANCY/123 & STANDARD DEVIATION (S) & CV-VARIATION COEFICIENT \\
\hline TYPE OF POLYMER & 26,9067 & & \\
Green PE & 6,7262 & 5,1871 & $12,6514 \%$ - Homogeneous \\
Green PP & 10,36 & 2,0611 & $6,3441 \%$ - Homogeneous \\
Green PP + PE & & 3,2186 & $7,8331 \%$ - Homogeneous \\
RESULTS & VAR-VARIANCY/123 & STANDARD DEVIATION & CV-VARIATION COEFICIENT \\
APLICATION & 38,0805 & 6,1709 & $10,33 \%$ - Homogeneous \\
PROCESS & 23,3234 & 4,2943 & $6,9826 \%$ - Homogeneous \\
PRODUCT & & \\
\hline
\end{tabular}

Source: Prepared by the author (2018)

For Shiguti [47] the variance of a set of data is the mean of the squares of the deviations of the values from the mean, which can be equated as follows (equation 1a and equation 1 b):

Equation 1a: VAR-VARIANCY- $\mathrm{S}^{2}$

$$
S^{2}=\sum \frac{(X i-X) 1^{2}}{(n-1)}
$$

Equation 1b: STANDARD DEVIATION (S)

$$
S=\sqrt{S^{2}}
$$

According to Shiguti [47], the standard deviation represents how much the sample deviates from the variance, therefore, for its calculation, it is first necessary to calculate the variance and then remove the square root to obtain the standard deviation.

Another measure used in this study was the coefficient of variation. It represents the relative mean in relation to the dispersion, which is useful for the comparison and observation of the degree of concentration around the average of different series, as is the case of the sample of this study. The dispersion distribution can be classified as:

Low dispersion: $\mathrm{CV} \leq 15 \%$ - homogeneous sample;

Mean dispersion: $15 \%<\mathrm{CV}<30 \%$ - average sample homogeneity;

High dispersion: $\mathrm{CV} \geq 30 \%$ - heterogeneous sample.

Considering Shiguti [47], conceptual explanation, the results presented in Table 2 show that the sample is homogeneous, since all the values obtained for the coefficient of variation show $\mathrm{CV} \leq 15 \%$, so dispersion is low in relation to the measurements of dispersion presented. It can be asserted, thus, that the data are reliable.

According to Oliveira [48], in the report on competition mechanisms published by the Copenhagen Economics Institute, there is no indicator that faithfully reflects the intensity of competition, since this is a complex, multidimensional and dynamic phenomenon, and the market is constantly moving in search for balance.

On the other hand, the Copenhagen Economics Institute also points out indicators to measure market concentration. The indicator used in this study was the HHI, which refers to the size of countries' participation in the patent market. A market with only one firm has an HHI of 1, that is, it will present high concentration and dominance of that market. When the HHI is close to 0 , it means that there is low concentration in that market $(\mathrm{q})$, that is, there are many participating companies. Equation 2 is used to calculate the HHI:

Equation 2:

$$
H=\sum q^{2} i
$$

According to the Departamento de Estudos Econômicos (Brazilian Department of Economic Studies), the HHI is an analytical tool developed to monitor the evolution of competition within markets and between different sectors. In this study, the index was applied to evaluate the participation of countries in the patent database, allowing it to assess the concentration of the patent market for green PEs and PP.

$\mathrm{HHI}$ is objective in nature, focusing on the concentration and competition of this market or segment, and it is very important for the understanding of market concentration. In an environment where there is a perfect competition model, 
the HHI would be more homogeneous and closer to 0 , indicating low market concentration and, therefore, space for entrants, that is, more companies or countries acting in the patent market for green PEs and PP. However, the results of this work show that there is imperfect competition and that there is a trend of market concentration due to the presence of important economic factors, such as economies of scale, applied technology and production factors, like the use of ethene from ethanol.

Table 2 shows the information from the point of view of the Market Concentration Index - HHI.

Table 2. Market Concentration Index.

\begin{tabular}{lllll}
\hline STATISTICAL TABLE OF RESULTS & & & & \\
\hline COUNTRIES OF ORIGIN & FREQUENCY & AVERAGE & HHI & NORMALIZED HHI \\
\hline EUA & 93 & $93 / 123=0,7560$ & 0,5715 & 0,5 \\
BRAZIL & 12 & $12 / 123=0,0975$ & 0,0095 & $-0,15$ \\
JAPAN & 9 & $9 / 123=0,07317$ & 0,007317 & $-0,157$ \\
INDIA & 4 & $4 / 123=0,0325$ & 0,001056 & $-0,165$ \\
BELGIUM & 1 & $1 / 123=0,0081$ & 0,0000656 & $-0,166$ \\
GERMANY & 1 & $1 / 123=0,0081$ & 0,0000656 & $-0,166$ \\
CHINA & 1 & $1 / 123=0,0081$ & 0,0000656 & $-0,166$ \\
RESULT & 123 & $123 / 7=17,5714$ & & \\
\hline
\end{tabular}

Source: Prepared by the author (2018)

It can be observed that the HHI of the USA is closer to 1 . The country, therefore, presents high concentration and dominance in the patent market. The other countries have HHI close to 0 , that is, low concentration and dominance of that market.

\subsection{Braskem and Its Gains in the Stock Exchange with BRKM5 and with Carbon Credits}

Braskem has three assets that are traded on the São Paulo Stock Exchange: BRKM3, BRKM5 and BRKM6. Out of these three assets, only BRKM5 is considered operative in the low carbon economy, being ranked in the Carbon Efficient Index (ICO2) of the São Paulo Stock Exchange (B3). Since B3 had access to the Braskem emissions reports to rank the company in the $\mathrm{ICO}_{2}$, this information should have been made available for the public but was not. It should be highlighted that green PEs are the only assets in the BRKM5 portfolio, because green Ethylene Vinyl Acetate (EVA) and green PP are not yet produced on an industrial scale. The stock exchange is a speculative market, so when the production of green PP was announced in 2011 and the production of green EVA was announced in 2016, there was much speculation on the financial market for the purchase of the BRKM5 stock [49]. PE is a commodity, that is, a highly consumed material around the world, particularly in the plastic and packaging industry. Braskem's production capacity for green PEs is approximately $1.23 \%$ of the total $\mathrm{PE}$ production of Braskem.

In 2010, five patents on green PEs and PP were granted. In 2010, Braskem announced the production of green PE on an industrial scale at the Triunfo plant. In 2011, there was an increase in patents, totaling 9. In the following years, 2012 and 2013, the number of patents more than doubled, to 20 and 23 documents, respectively. As of 2013 , the number of patents granted has fallen (20 documents in 2014, 14 in 2015 and 13 in 2016). In 2017, only one patent document was filed. The question is which factors contributed to such decline.

Since BRKM5 is a commodity traded over the counter at
B3 (Open Market) and this commodity is also traded on the New York Stock Exchange, it is a highly speculative asset, that is, any positive information regarding the company's assets promotes an elevation of its average prices. Since Green PEs account for the largest share of BRKM5 assets, Braskem is responsible for the pricing of green PEs on the stock markets in which it is listed around the globe.

After Braskem went public on B3, with the BRKM5 asset, the Company's stock gains only increased. It should be highlighted that, although Braskem has never produced green $\mathrm{PP}$ on an industrial scale, the announcement that it would do so in 2011 and again in 2016, helped to raise the average prices of the BRKM5 assets, due to the speculative nature of the financial market. In 2012 the average share price was $\mathrm{R} \$ 13.27$ and, in 2018 , the average price reached $\mathrm{R} \$ 48.93$ per share, that is, a $\mathrm{R} \$ 35.66$ growth in the average share price of BRKM5 in 6 years, representing an increase of $268 \%$.

In 2007, Braskem announced that it was going public on B3 and that it would produce green PE. At the company's initial public offering, the asset price reached $\mathrm{R} \$ 16.12$ per share. In 2008, the company announced that it would produce green PP, which did not occur, and the market responded with lower average asset prices. In 2009, the financial market responded well to the announcement of a partnership with Novoenzyme for the production of green PP from sugarcane. The information caused a slight rise in asset prices, giving the asset a speculative character. In 2010, the company started selling green PE and began certifying the products with the label "I'm green ${ }^{\mathrm{TM}}$ ". The market's response was not exceptional, but asset prices remained high. In 2011, the information that a renowned company like Vinçotte would certify the renewable content of Brakem's products was not enough to maintain the average asset price stable on B3 and prices fell. The drop continued until 2013. In 2013, Braskem entered the USA financial market and was first listed on the Dow Jones Sustainability Index. With this new fact, average prices rose again, from $\mathrm{R} \$ 13.88$ to $\mathrm{R} \$ 16.88$. In 2014, Braskem announced the construction of a new UTEC plant in the USA. UTEC is Braskem's registered trade mark for Ultra- 
High Molecular Weight Polyethylene (UHMWPE) technology, a fossil polymer. This helped to keep the company's average asset prices high on B3. In 2015, when green plastic completed five years on the market and the company's image was consolidated worldwide, average asset prices increased significantly from $\mathrm{R} \$ 18.01$ to $\mathrm{R} \$ 26.94$, generating extraordinary profits for the company. In 2016, despite having announced that it would produce green PP and that it had started production of the "I'm green ${ }^{\mathrm{TM}}$ " Evance resin (green EVA), the company's assets depreciated somewhat in the financial market [49].

The great price boom for Braskem's assets took place in 2017, shortly after the company inaugurated the UTEC plant in the USA and also joined the Carbon Disclosure Project (CDP). The average asset price was $\mathrm{R} \$ 24.31$ and rose to $\mathrm{R} \$ 43.91$. The high continued in to 2018 , as the assets closed the trading session at the price of $\mathrm{R} \$ 48.93$.

The results of the AIS from 2007 to 2018 show that the company's stock earnings grew year after year, shortly after the initial public offering on B3. The company's entry into the international market and into the world's major stock markets has contributed to the achievement of extraordinary profits. In this sense, one might argue that the company could increase its profits with securities, without making additional investments in research to increase the production of green ethene, the raw material which green PEs and PP are made of. The production of green ethene has always been the same, i.e. $200,000 \mathrm{t} / \mathrm{y}$. A company that presents liquidity of its assets is of high interest for the financial market and for investors. Therefore, it is likely that when Braskem consolidated its position in the national and international financial markets, its management realized there was no need to maintain high investments in new technologies or patents related to the production of green PEs. Instead, they needed to stay in the securities market [49].

Table 3 shows the AIS of the company's stock earnings over the period 2007 to 2018. The values in dollars refer to the December quotation of each year.

Table 3. Gross AIS Result X Year.

\begin{tabular}{llll}
\hline YEAR & $\begin{array}{l}\text { DRE-REVENUE-EXPENSES-BRASKEM S. A } \\
\text { R MILLION }\end{array}$ & NOMINAL RATE EXCHANGE USS & COVERSION: REAL-DOLLAR \\
\hline 2007 & $1.696,29$ & 1,79 & $947.647,49$ \\
2008 & $1.842,84$ & 2,39 & $771.061,09$ \\
2009 & $3.138,27$ & 1,75 & $1.793 .294,85$ \\
2010 & $3.491,53$ & 1,69 & $2.065 .995,85$ \\
2011 & $3.163,69$ & 1,84 & $1.719 .384,78$ \\
2012 & $2.445,58$ & 2,08 & $1.175 .757,69$ \\
2013 & $3.731,67$ & 2,35 & $1.587 .766,38$ \\
2014 & $4.444,24$ & 2,64 & $1.683 .424,62$ \\
2015 & $7.572,24$ & 3,87 & $1.956 .662,27$ \\
2016 & $9.734,48$ & 3,35 & $2.905 .815,52$ \\
2017 & $9.614,93$ & 3,29 & $2.922 .470,21$ \\
2018 & $9.618,24$ & 3,98 & $2.146 .641,92$ \\
RESULT & $60.493,54$ & & $21.945 .922,69$ \\
\hline
\end{tabular}

Source: Prepared by the author (2018).

The AISs from 2010, when Braskem started production of green PE, until 2017, show there was growth of revenues. However, although revenues increased in the period, it can be observed that in the period that presents the highest gains in the AIS was from 2007 to 2014. In turn, between 2015 and 2018, the peak of the economic crisis in Brazil, there was a flight of foreign capital, since the Brazilian real was devalued. In addition, Braskem's stock earnings on B3, shown year by year in Table 3, total $\mathrm{R} \$ 60,493,542.00$ from 2007 to 2018. Thus, it can be argued that the reason why there has been a fall in the number of patents over the years is that capital gains are larger and require smaller investments.

In order to calculate how much Braskem profits from the carbon credits obtained from the production of green PEs, one must consider that for every ton of green ethene produced, 85.2 tons of sugarcane are needed, which remove 4,75 tons of $\mathrm{CO}_{2}$ from the atmosphere [11]. Braskem produces 200,000 tons of green ethene per year in the Triunfo plant. Considering that the average price of the carbon credit asset on BVRIO was in 2018 US $\$ 8.00$, and multiplying that number by $950,000(4,75 \times 200,000)$ tons of $\mathrm{CO}_{2}$ removed from the atmosphere, with the production of the 200,000 tons of green ethene, total for 2018 would be US\$7,600,000 (The calculation was made according to the information provided by Braskem's video of 2018). In short, Braskem could have earned approximately US\$7,600,000 in 2018 , related to the trading of carbon credits resulting from the production of 200,000 tons of green ethene obtained from the dehydration of ethanol from sugarcane. Braskem's profits with carbon credits from 2010 to 2017 can be calculated based on the closing price of the trading session for the green asset. It appears, therefore, that the gains from carbon credits in the period were greater than the gains in the AIS. For this reason, it is important to carry out studies on the company's balance sheet, not available despite SOX requirements, between 2007 and 2018, to verify what were the actual earning's related to the company's assets (BRKM3, BRKM5 and BRKM6).

It should be highlighted that, considering all of Braskem's polymer production units, the company's overall carbon emissions are higher than the amount of carbon dioxide that the green PEs plant removes from the atmosphere. Its approximate production of $200,000 t / y$ is 
much smaller than the production of polymers of fossil origin. Braskem is considered a green company because it is more sustainable than others, which do not produce green polymers.

The prospect of increasing the production of green ethene is small because sugarcane already occupies $0.02 \%$ of the Brazilian ploughed land, as it meets current demand [6-8]. However, even if the "I'm green ${ }^{\mathrm{TM}}$ " EVA and PP are produced on an industrial scale, or any other polyaddition polymer that uses ethene as a raw material, the profits from BRKM5 on B3 will be very high. In other words, speculation in the production of Braskem new green polymers at the expense of the same amount of green ethene produced today is a device for capital gains.

\section{Conclusion}

The USA presents high concentration and dominance in the green polyethylenes and green polypropylene patent market. The American dominance for the patent market is compatible with the oligopolistic structure of the market, where the one that dominates the market dictates the rules of prices of products, goods or services. However, Braskem, a Brazilian company, is the only company in the world that produces nonbiodegradable green polyethylene (HDPE and LLDPE) that are biopolymers. Green ethene derived from the dehydration of sugarcane ethanol is an important ally in the decarbonization of the environment although Brazil lacks a systematic control in order to demand transparency in companies that profit with green technologies. Green ethene not only generates carbon credits and profits but also opens a wide range of possibilities for the production of green polymers. Although Braskem produces only 200,000 ton/year of green PEs, $1.23 \%$ of the total production of PEs, the profits in the stock exchange in $\mathrm{B} 3$ with the green stock (code BRKM5) are much higher than with the fossil stocks (codes BRKM3 and BRKM6) and reached 268\% between 2012 and 2018. Braskem manages to make extraordinary profits using the production (industrial or in a laboratory scale) of green polymers, environmental appeal and a marketing strategy that uses the "I'm Green TM", label. Even if the green polymer is blended with fossil one (up to $49 \%$ ), the material will be considered green, and will live up to the label "I'm Green TM".

\section{Declarations of Interest /Conflicts of Interest}

All the authors do not have any possible conflicts of interest.

\section{Author Contribution}

Eliana Hellvig: doctorate student in the Post-graduation course in Mechanical Engineering (PGMec), Paraná Federal University (UFPR); Thais Flores-Sahagun: supervisor professor.

\section{Acknowledgements}

The authors wish to thank the National Council for Scientific and Technological Research (CNPq) for the Fellowship to one of the author (CNPq Process No. 304421/2017-0) and to the company BRASKEM S/A that sent us polymer samples (HDPE and LLDPE green and fossil. The authors would also like to thank Tamara Flores-Sahagun and the Academic Publishing Advisory Center (Centro de Assessoriade Publicação Acadêmica, CAPAwww.capa.ufpr.br) of the Federal University of Paraná (UFPR) for assistance with English language editing.

\section{References}

[1] WATERS, N.; VALVO, N. Synthesis of green polyethylene from sugarcane-based ethanol. Access June10, 2018. WIPOWorld Intellectual Property Organization. USA: Autor. In: $<$ http://www.wipo.int/pct/pt.>Access Jun10, 2018.

[2] BORSATTO, J. M. L. S; BAZANI, C.; AMUI. L. Regulamentações Ambientais, Inovação Verde e desempenho: Uma análise de empresas dos setores industrial de países desenvolvidos e países em desenvolvimento. BBR. In $<601$ Articule\%20text-1775-1-10-20200727\%20(2).pdf> Access July, 2020.

[3] PEREIRA, A. F. A; STOCKER, F; MASCENA, K. M. C; BOAVENTURA. J. M. G. Desempenho social e desempenho financeiro em empresas brasileiras: Análise da influência do Disclousure. BRR-<Articule\%20Text-1779-1-1020200727.PDT > Access July, 2020.

[4] APAK, S., \&ATAY, E. (2015). Global competitive nests in the EU through green innovation technologies and knowledge production. Procedia-Social and Behavioral Sciences, 181, 207- 217. https://doi.org/10.1016/j.sbspro. 2015.04.882

[5] OKSMAN, K.; MATHEW, A. P.; BISMARCH, A.; ROJAS, O.; SAIN, M. Handbook of green materials-Processing Technologies Properties and Application, v. 5, 1124 pages. DOI-101142/8975, June 2014.

[6] AMAN, E.; BAER, W.; COES, D. V. Energy bio fuels and Development-Comparing Brazil and The United States. Routl edge Studies in Development Economics, 334 pages, ISBN97780415746359, 2013.

[7] DIAS, M. O. S.; FILHO MACIEL, R.; MANTELATTO, P. E.; CAVALETTI, O.; ROSSELL, C. E. V.; BONOMI, A.; LEAL, M. R. L. V. Sugarcane processing for ethanol and sugar and Brazil. Environmental Development, v. 15, p. 35-41, 2015.

[8] GARCÍA, C. A; FUENTE, A.; RENNECKE, A; RIEGELHAUPT, E.; MANZINI, F. and MASERA, O. Lifecycle green house gas emissions and energy balance of sugarcane ethanol production in Mexico. In Access 11 June 2020.

[9] COUTINHO, Fernanda ET al. Polietileno: Principais Tipos, Propriedades e Aplicações. Revista Ciencia e Tecnologia, v. 13, n um, p. 1-13, 2003. Disponível em< http://www.scielo.br/pdf/po/v13n1/15064.pdf> Acessado em 09 de jan de 2016.

[10] BASTOS, V. D. Biopolímeros e polímeros de matérias-primas renováveis alternativos aos petroquímicos. Revistado BNDES, 14(28), 201-234, 2007. 
[11] BRASKEM: Plástico Verde. In: Access José 11, 2020. BOLSA DE VALORES DE SÃO PAULO- B3: Índice de Sustentabilidade. São Paulo. In: Access June 9, 2020.

[12] SAJID, M. J. Inter-sectoral carbon ties and final de mand in a high climate risk country: The case of Parkistan. JCLE, doi101016/j.jclepro.2020.122254, v. 269, 2020.

[13] QU, C.; SHAO, I.; CHENG, Z. Can embedding in global value chain drive green growth in China's manufacturing industry? JCLP, https://doi.org/10.1016/j.jclepro.2020.121962, 2020.

[14] HELLVIG, F. L. Eliana. Estudo sobre a inovação, patentes concedidas de polipropileno e polietilenos verdes no período de 1999 a 2017 e sua relação com a descarbonização do meio ambiente: o caso BRASKEM. Tese de Doutorado - UFPR, 2019.

[15] OLIVEIRA, L. B.; RUSSO, S. L.; MARQUES, L. G. A., GOMILA, J. M. V. Technological productivity on control of Boophilus Microplu stick: A patentometric study". Int. Journal of Advanced Engineering Research and Science, v. 6 (2), p. 134-143, 2019.

[16] ASSAF, Alexandre Neto. Mercado Financeiro. 12a edição. São Paulo. Editora: Atlas, 2012.

[17] BOVESPA- B3: Índice de Sustentabilidade. In $<$ www.b3.com.br/pt_br/market-data-eindices/indices/indicesde-sustentabilidade/>Access July13, 2019.

[18] BACEN. Banco Central do Brasil. In: Access October 2, 2019

[19] MENEGUETTI, N. A. A Reconstrução Produtiva do Setor Sucroalcooleiro no Brasil de 1975 a 1999. Dissertação de mestrado, UEM, 2019.

[20] MOHANTY, A.; MISRA, M.; DRZAL, L. Sustainable biocomposites from renew able resources: opportunities and challenges in the green materials world. Journal of polymers and the Environment, v. 10, n. 1-2, p. 19-26, 2002.

[21] DE PAOLI, Marco Aurelio. Degradação e Estabilização de polímeros. 2 $2^{\mathrm{a} e d i c ̧ a ̃ o . ~ S a ̃ o ~ P a u l o . ~ E d i t o r a: ~ A r t l i b e r, ~} 2008$.

[22] SCOTT, G. Green polymers. Polymer Degradation and Stability, v. 68, n. 1, 2000.

[23] ALTINBALIK, T.; EKSI, O.; KARABEYOGLUS. CABBAR, E. Thermo forming of biopolymer-green polyethylene sheets. Int. J. of Modern Manufacturing Technologies, v. 10 (2), p. 2067-3604, 2018.

[24] XU, J.; XIA, R.; ZHENG, L.; YUAN, T.; SUN, R. Plasticized hemicelluloses/chitos an based edible films reinforced by cellulose nano fiber with enhanced mechanical properties. Carbohydrate Polymers, v. 224, 115164, 2019.

[25] GONZÁleS, G.; GASTELÚ, G. N.; BARRERA, P. D.; RIBOTTA, C. I. A. IGARZABAL. Preparation and characterization of soy protein films reinforced with cellulose nanofibers obtained from soy beans by-product. Food hydrocolloids, v. 89, p. 758-764, 2019.

[26] MARTELLI-TOSA, M.; MASSON, M. M.; SILVA, N. C.; ESPOSTO, B. S.; BARROS, T. T.; ASSIS, O. B. G.; TAPIABLÁCIDO, D. L; Soy beans trawl nanocellulose produced by enzymatic or acid treat ment as are iforcing files in soy protein so late films. Carbohydrate Polymers, v. 198, p. 61-68, 2018.

[27] CAO, L.; GE, T.; MENG, F.; XU, S.; LI, J.; WANG, L. Inedible oil packaging film with improved barrier properties and heat sea lability from cassia gumin corporating carboxy lated cellulose Nano crystal whisker. Food hydrocolloids, v. 98, 105251, 2020.

[28] DICKER, M. P. M.; DUCKWORTH, P. F.; BAKER, A. B.; FRANCOIS, G.; HAZZARD, M. K. Green composites: a review of material attributes and complementary aplications. Composites part A, v. 56, p. 280-289, 2014.

[29] MOSTAFA, H.; YOUSSEF, A. M; DARWISH, N. A; ABOU-KANDIL, A. I. Ecofriendly polymer composites for green packaging: future vision. Composites Part B, v. 172, p. 16-25, 2019.

[30] LIN, Y. S; KUO, P. Y. Tailored optical and mechanical properties of nanocellulose composites: From green natural fibers trough brid reinforcements. Earth Environments Science, v. 268, 012140, 2019.

[31] HEGYESI, N.; ZHANG, Y.; KOHÁRI, A.; POLYAKE, P; SUI, X.; PULÁNSZKY, B. Enzymatic degradation of PLA/cellulose nanocrystal composites. Industrial Crops \& Products, v. 141, 111799, 2019.

[32] SEONE, I. T.; CERRUTI, P.; VASQUEZ, A.; CYRAS, V. P.; MANFREDI, L. B. Ternary nanocomposities based on plasticized poly(3-hydroxybutyrate) and nanocellulose. Polymer Bulletin. In: 2018.

[33] PLATNIEKS, O.; BARKÃNE, A.; IJUDINA, N.; GAIDUKOVA, G.; THAKUR, V. K.; GAIDUKOVA, S. Sustainable tetrapak recycled cellulose/poly (butylenesuccinate) based woody-like composites for a circular economy. JCLP, https://doi.org/10.1016/j.jclepro.2020.122321,2020.

[34] HEINZEN, D. A. D. M.; MATTOS, A. P. M. N.; CAMPOS, L. M. D. S. \& PALADINI, E. P. Estudo de viabilidade de produto inovador "verde" para o mercado consumidor comum. Revista Gestão Organizacional, 4 (2), 122-131, 2011.

[35] NEVES, M. F.; TROMBIN, V. G.; CONSOLI, M. A. Measurement of sugarcane chain in Brazil. International Food and Agribusiness Management Review. v. 13. n. 3. p. 37-54, 2010 .

[36] REIS, G. G. Inovação no Desenvolvimento de Plásticos "Verdes" e com menores Carbon Footprints: O caso do Polietileno de álcool de cana de açúcar da Braskem. ANPADEstudos em Estratégia IV Encontro, 2009.

[37] RODRIGUES, R. A. J. Do Engenho à Biorrefinaria. A Usina de açúcar como empreendimento industrial para a geração de produtos bioquímicos e biocombustíveis. Química Nova, v. 34, n. 7, p. 1242-1254, 2011.

[38] HellviG, E. L; FlORES-SAHAgUN, T. H. S. Desenvolvimento Sustentável para empresas brasileiras: a nova proposta da Economia Hipocarbônica como estratégia de obtenção de lucros através dos créditos de carbono. Revista Brazilian Journal of Development, v. 6 (5), p. 25456-25472, 2020 .

[39] HELlVIG, E. L; FLORES-SAHAGUN, T. H. S.; CARVALHO FILHO, M. A. S.; GONZALES, R. M.; TANOBE, V. O. A; SANTAMARIA, L. C; RAMIREZ, M. G. L. Estudo do uso de eteno verde ou fóssil na síntese de PEAD e PELBD nominalmente iguais: há diferença efetiva entre esses materiais? Revista Brazilian Journal of Development v. 6 (5), p. 25473-25487, 2020. 
[40] RAMIRES, E. C.; MEGIATTO, J. D. JR.; GARDRAT, C.; CASTELLAN, A.; FROLLINI, E. Biobased composites from glyoxal-phenolicres ins and sisal fibers. Bio resours Technol, v. 101, n. 6, p. 1998-2006, 2010.

[41] NARAJAN, R. Drivers \& Rationale for Use of Biogases Materials Based on Life Cycle Assessment (LCA). Global Plastics Environmental Conference, Detroit, February18-19, 2004.

[42] GIANNETTI, B. F. \& de ALMEIDA, C. M. V. B. Ecologia industrial: conceitos, ferramentas e aplicações. Editora: Edgard Blücher. São Paulo, 2006.

[43] GEYER, Roland; BLASS Vered Doctori. The economics of cell phone reuse and recycling. Int J. Adv. Manuf. Technol. V. 47, p. 515-525, 2010.

[44] FALCONE, B. M. D. Panorama Setorial e Perspectivas na Área de Polímeros Biodegradáveis. Polímeros: Ciência e Tecnologia, v. 17, n. 1, p. 5-9, 2007.

[45] LANCELlOTTI, A. Bioplastics in Brazil: Beyond the Green Speech. Frost \& Sullivan. São Paulo: Autor. In: $<$ www. frost.com $>2010$.

[46] JESUS, S. M. S.; OLIVEIRA Jr, A. M. Patentometry analysis of the transfer of technology in Brazil between 2010 and 2018. Int. J. Of Innovation Education and Research, v. 7 (7), 112123, 2019.

[47] SHIGUTI, A. Wandereley. Apostila de Estatística, 2006. Disponível: $\quad$ http://www.inf.ufsc.br/ paulo.s.borges. Química.pdf. Acessado em 20 de mar de 2018 as 14 horas.

[48] Oliveira, G. A. S. Indicadores de Concorrência. Documentos de Trabalho: 001/2014 do Conselho Administrativo de Desenvolvimento Econômico (CADE). Recuperado de: http://www.cade.gov.br/acesso-a-informacao/publicacoesinstitucionais/dee-publicacoesanexos/documento-de-trabalhon-01-2014-indicadores-de-concorrencia.pdf/view. Acessado em 18 de jan 2019 as $10 \mathrm{~h}$.

[49] HELlVIG, E. L; FLORES-SAHAGUN, T. H. S. Os ativos verdes da Braskem x patentes verdes como instrumentos econômicos para descarbonização do meio ambiente: polipropileno epolietilenos verdes. Revista Econômica do Nordeste. Publicação aceita para publicação Jul/Set. 2021.

[50] HellviG, E. L; Flores-Sahagun, T. H. S. The Importance of Public Policies That Encourage Companies To Decarbonizes The Environment And Invest In Clean Technologies In Brazil. Revista Mexicana de Ingeniería Química. vol. 20, n. 2 (2021) 889-910. March 7, 2021. 